\title{
MISCELLANEOUS DESCRIPTIONS OF NEW PARASITIC HYMENOPTERA WITH SOME SYNONYMICAL NOTES
}

\author{
By A. B. GaHaN \\ Of the Bureau of Entomology, United States Department of Agriculture.
}

This paper contains descriptions of one new species of Braconidae, three new genera and seventeen new species of Chalcidoidea and one new species of Scelionidae. Most of these supposed new forms are from the United States, but one new genus and species from New Zealand, two new genera and species from Java, two new species from Costa Rica, and two new species from Porto Rico, are included. Synonymical notes likewise include notes on species falling in Braconidae, Chalcidoidea, and Scelionidae.

\section{Superfamily ICHNEUMONOIDEA}

\section{Family BRACONIDAE}

\section{OPIUS FULVICOLLS Thomson}

Opires fulvicollis Thомson, Opuse. Entom., pt. 20, 1895, p. 2181, no. 9. Opius cupidus Gahan, Proc. Ent. Soc. Wash., vol. 21, 1919, p. 162.

Seven specimens of a species agreeing exactly with Thomson's description of $O$. fulvicollis were recently received from Dr. Hans Bremer, Stralsund, Pomerania, Germany, parasitic according to the sender upon Pegomyia hyoscyami Panzer. To the surprise of the writer these proved to be identical in every respect with $O$. cupidus Gahan described in 1919 from specimens taken in Manhattan and Brooklyn, New York City, and parasitic upon the same species of Pegomyia. The record is interesting as showing the occurrence of the species in both Europe and America as well as for constituting the first host record for $O$. fulvicollis known to the writer.

\section{DIOSPILUS CURTICAUDIS, new species}

This species may be separated at once from all of the other described American species by the short ovipositor which is exserted less than half the length of abdomen.

No. 2676.-Proceedings U. S. National Museum, Vol. 7I, Art. 4 $28453-27 \dagger-1$ 
Female.-Length $2.5 \mathrm{~mm}$. Head transverse, about twice as broad as long, distinctly narrowed behind the eyes; smooth and polished throughout; clypeus slightly rounded anteriorly, with a few obscure punctures along the anterior margin; antennae inserted a little above the middle of head, 24-jointed in the type, the first and second flagellar joints subequal and about twice as long as thick, following joints shorter, those toward apex barely longer than broad, all flagellar joints covered with short hairs; mesonotum smooth, parapsidal grooves deep and weakly foveolated; transverse groove at base of scutellum deep and divided by one earina in the middle; mesopleura smooth with moderately deep foveolated sternauli; propodum with a sinuate transverse carina before the middle, smooth in front of the carina, irregularly rugose behind the carina, the smooth basal portion divided by more or less distinct median longitudinal carina; stigma of forewing broad; radius arising from middle of stigma, its first abscissa not over twice as long as broad, second abscissa about two-thirds as long as first intercubitus; nervulus postfurcal by about half its length; recurrent joining first cubital cell; submedius with two indistinct stubs extending into the anal cell, the first near the middle of submedius and the second near the apex; hind tibial spurs subequal and less than half as long as the short basitarsus; abdomen shorter than the thorax, ovate; first tergite slightly longer than broad, broader at apex than at base, punctate and shining, the basal middle smooth; second and third tergites polished, subequal, together about as long as the first; tergites beyond the third very short, together not longer than the third; ovipositor extending beyond the apex of abdomen about one-third the length of abdomen.

Black; scape and legs including all coxae pale reddish testaceous; the flagellum, and basal half of hind tibiae as also the hind tarsi black; wings hyaline, costa and stigma black, rest of venation dark brown; ovipositor sheaths black.

Type locality.-Baton Rouge, Louisiana.

Type.-Cat. No. 29438, U.S.N.M.

Host.-Haltica litigata Fall.

Described from five females reared from larvae of the above mentioned host, March 15, 1923, by C. E. Smith, and recorded in the Bureau of Entomology under Chittenden No. 7082-1.

\section{Superfamily CHALCIDOIDEA}

\section{Family PTEROMALIDAE}

MERISUS HARMOLITAE, new species

Differs from $M$. destructor (Say) by being more slender, the abdomen subcylindrical, the antennal club a little less pointed at apex, and the legs more contrastingly colored. 
Female.-Length $2.3 \mathrm{~mm}$. Head transverse, a little broader than the thorax, about three times as wide as thick antero-posteriorly; occiput rather strongly concave; ocelli in a low triangle, the postocellar line longer than the ocellocular, the latter line equal to a little more than twice the greatest diameter of an ocellus; viewed from in front the head is a little broader than long; antennae inserted near the middle of head, distinctly above the lower eye-margins; antennal depression shallow; eyes bare; whole head with close reticulate-punctate sculpture, the sculpture of face below antennae slightly finer than that of frons; clypeus striate; antennal scape rather short; pedicel shorter than first funicle joint; ring-joints distinct but strongly transverse; first funicle joint a little longer than broad and very slightly longer than the second, second and third equal, fourth to sixth quadrate; club solid, weakly acuminate, slightly longer than two preceding funicle joints combined; thorax sculptured like the head; parapsidal grooves entirely effaced on posterior half of mesoscutum; scutellum and axillae a little more finely and not quite so deeply sculptured as mesoscutum; propodeum without a neck, more deeply punctured than scutellum, without median carina and without lateral folds, the spiracular sulci very faintly indicated but incomplete; spiracles short-ovate and small; wings ample; submarginal vein much longer than marginal; postmarginal and marginal equal; stigmal half as long as postmarginal, the stigmal knob a little enlarged; abdomen as long as thorax, and distinctly narrower, subcylindrical, tapering very slightly toward apex, first dorsal segment comprising a little less than one-third the total length, following segments subequal or successively increasing very slightly in length with the second segment the shortest; ovipositor concealed. Head and thorax dull metallic green; abdomen shining black with a weak metallic sheen in some lights; antennae dark brown above, the scape, pedicel and funicle testaceous beneath and the club mostly testaceous; all coxae and all femora concolorous with the thorax; distal ends of all femora, the tibiae, and tarsi pale yellow, the apical joint of tarsi dark brown: wings hyaline, venation pale brownish.

Male.-Length $1.8 \mathrm{~mm}$. Antennal scape short, not more than three times as long as broad; pedicel scarcely longer than broad; first funicle joint about three times as long as pedicel and distinctly thicker than pedicel; second funicle joint shorter than the first but approximately twice as long as broad; following joints all longer than broad; club only slightly thicker than funicle and subequal in length to two preceding joints; thorax and abdomen unusually slender; otherwise like the female.

Type locality.-Bird's Landing, California.

Type.-Cat. No. 29439, U.S.N.M.

Host.-Harmolita grande Riley. 
Two females and one male from the type locality received from $\mathrm{C}$. M. Packard under Pasadena No. 2358 and said to have been "reared from Harmolita grande material" May 7, 1923. One female from Altamont, California, also received from Packard and reared from the same host.

\section{MERISUS ATRISCAPUS, new species}

This strikingly colored form resembles $M$. flaviventris Girault, but the females may be distinguished by the somewhat shorter and broader abdomen, by the strongly brass-tinted mesoscutum, and by the median broad blackish stripe on the venter.

Female.-Length $2.4 \mathrm{~mm}$. Head broader than the thorax, about three times as broad as thick antero-posteriorly; occiput moderately concave; ocelli in an obtuse triangle, the postocellar line a little longer than the ocellocular, the latter line equal to a little more than twice the greatest diameter of an ocellus; viewed from in front the head is broader than high, antennae inserted only very slightly above the lower eye-margins; eyes bare and rather short; cheeks rather long, about three-fourths as long as the eyes; antennal depression shallow; clypeal region with converging striae; remainder of head rather strongly reticulate-punctate; scape not quite reaching to the front ocellus; pedicel subequal to the ring-joints and first funicle joint combined; ring-joints distinct but transverse; funicle joints 1 to 4 a little longer than broad, joints 5 and 6 subquadrate; club conical, nearly as long as the three preceding joints combined and pointed at apex. Thorax rather slender; mesoscutum with shallow reticulate-punctate sculpture, parapsidal grooves effaced on posterior half; scutellum and axillae similarly but more finely sculptured; propodeum medially sculptured nearly like the scutellum, laterally more weakly sculptured, without a median carina, the lateral folds represented by a deep basal fovea on either side of the middle, spiracular sulci weakly impressed, spiracles narrow elliptical; hind tibiae at apex behind with two very short spines; marginal and postmarginal veins equal, and together equal to the submarginal; stigmal slightly more than half as long as postmarginal; abdomen broader than thorax and about as long as thorax, ovate, acute at apex, depressed above, the apex of ovipositor barely visible from above. Mesoscutum brassy; remainder of thorax, propodeum, head, and all coxae bluish black; scape and pedicel concolorous with the head; apex of pedicel and entire flagellum pale stramineous; legs, except coxae, stramineous with the femora basally more or less tinged with brownish and the apical tarsal joint blackish; wings hyaline the venation pale stramineous; abdomen above pale straw-colored with the extreme base narrowly blackish, the venter brownish black medially with broad lateral margins concolorous with the dorsum. 
Male.-Length $1.5 \mathrm{~mm}$. Antennal scape short, slightly swollen beyond the middle, about three and one-half times as long as its greatest breadth; pedicel about one and one-half times as long as broad; flagellum of a nearly uniform thickness throughout, conspicuously hairy, the hairs about as long as the joints; ring joints very small; first funicle joint about twice as long as thick and slightly longer than pedicel, second to sixth joints successively diminishing very slightly in length, the sixth barely longer than broad; club no thicker than the funicle, about equal in length to the three preceding funicle joints, indistinctly three-jointed, the apical joint conical and sharp at apex; head and thorax with the sculpture not quite so deep as in the female; abdomen not as broad as thorax, narrowly elliptical in outline, about as long as thorax. Mesoscutum slightly brassy ; remainder of thorax, propodeum, head, and coxae bluish-black; antennae black throughout, or with the flagellum slightly brownish-black; all femora dark brownish on basal half or two-thirds, the remainder of legs pale yellowish except apical joint of tarsi which is brownish; abdomen bluish-black or brownish-black above and below, with a pale spot before the middle. Other characters as in the female.

Type locality.-Beach, North Dakota.

Type-Cat. No. 29440, U.S.N.M.

Seven females and four males reared by C. N. Ainslie from stems of Stipa comata in August and September, 1923, under Webster No. 23396. The host is not known.

\section{MORMONIELLA VITRIPENNIS (Walker)}

Pteromalus vitripennis WaLker, Ent. Mag., vol 3, 1836, p. 492.

Pteromalus abnormis Bohrman, Ofvers. Svensk. Vet.-Akad. Forh., vol. 15, 1858, pp. 58 and 59 , pl. 2, fig. 3 .

Mormoniella brevicornis Ashmead, Mem. Carn. Mus., vol. 1, 1904, p. 316.

Nasonia brevicornis Ashmead, Mem. Carn. Mus., vol. 1, 1904, p. 317.

Nasonia brevicornis Girault and Sanders, Psyche, vol. 16, 1909, p. 119; vol. 17, 1910 , p. 9.

Nasonia brevicornis Brues, Can. Ent., vol. 42, 1910, p. 260.

Nasonia brevicornis Grrault, Mem. Queensland Mus., vol. 2, 1913, p. 307.

Mormoniella brevicornis Kundumov, Rev. Russ. d'Entom., vol. 13, 1913, p. 5.

Lariophagus abnormis KuRdJumov, Rev. Russ. d'Entom., vol. 13, 1913, p. 15.

Nasonia brevicornis Froggatt and McCarthy, Agr. Gaz. New South Wales, vol. 25,1914 , pt. 9 , p. 759 .

Nasonia brevicornis Girault, Mem. Queensland Mus., vol. 3, 1915, p. 316.

Nasonia brevicornis RouBAud, Bull. Scient. France et Belgique, Paris, vol. 1, no. 4.

1917, pp. 425-429; Rev. Appl. Ent., ser. B, vol. 5, 1917, p. 157.

Nasonia brevicornis Froggatт, Dept. Agr. N. S. Wales, Farm. Bull. 113, 1917, p. 28.

Nasonia brevicornis Froggatt, Bull. Ent. Res. Lond., vol. 9, 1919, pp. 257-262. Nasonia brevicornis Graham-Smith, Parasitology, vol. 11, p. 372, figs. 14-15.

Nasonia brevicornis Alston, Proc. Zool. Soc. Lond., 1920, pt. 3, pp. 216-241, figs. 13-20.

Nasonia brevicornis Girault, Proc. U. S. Nat. Mus., vol. 58, 1920, p. 214. 
Nasonia brevicornis Johnston, Sci. and Industry, Melbourne, vol. 2, 1920, p. 310. Nasonia brevicornis Johnston and Bancroft, Proc. Roy. Soc. Queens!., vol. 32 , 1921, p. 24.

Nasonia brevicornis Johnston and Tregs, Proc. Roy. Soc. Queensl., vol. 33, 1921, pp. 99-102, 104, 111-118, and 126, pl. 10, figs. 20-22.

Nasonia brevicornis Austen and Hegh, Pub. Imp. Bureau Ent., 1922, p. 134.

Nasonia brevicornis Johnston, Trans. and Proc. Roy. Soc. So. Australia, vol. 47, 1923 , p. 205.

Mormoniella brevicornis GaHAN and FAGAN, Bull. 124, U. S. Nat. Mus., 1923, p. 91 and 93.

Mormoniella brevicornis Parker, Ann. Soc. Ent. Fr., vol. 93, 1924, p. 309, fig. 142.

Mormoniella brevicornis Timberlake, Proc. Haw. Ent. Soc., vol. 5, 1924, p. 421. Mormoniella, species Hardy, Queensl. Agric. Jour., 1924, p. 349; 1925, p. 347.

Brues in 1910 and Kurdjumov in 1913 pointed out that Nasonia Ashmead and Mormoniella Ashmead were synonyms with the same species as genotype. The type species has usually been referred to as Nasonia brevicornis Ashmead and has been recorded from many parts of the world and much written about its habits and biology.

T. Harvey Johnston in 1923 doubtfully suggested that $N$. brevicornis Ashmead and Pteromalus abnormis Boheman were the same species. A recent letter from G. H. Hardy of the University of Queensland, Brisbane, Australia, requested an opinion from the writer regarding this synonymy. A careful comparison of specimens with Boheman's description and figures was accordingly made with the result that they were found to agree very well. Boheman originally recorded his species from Europe as probably parasitic upon the puparium of a sarcophagid. Nasonia brevicornis has been recorded from Europe and specimens reared by H. L. Parker from puparia of Sarcophaga, species at Hyeres, France, have been compared with Ashmead's types by the writer and found to agree in every way. In view of this agreement as to host and general habitat as well as description, the writer became convinced that brevicornis Ashmead and abnormis Boheman were the same species.

This fact was mentioned in a letter to my good friend Dr. James Waterston, of the British Museum, who informed me of his agreement with the conclusion in so far as it went, but who added the interesting information that Pteromalus abnormis was not the oldest name for the species since Pteromalus vitripennis Walker, the type of which was still in good condition in the British Museum, was identical. Waterston further stated that he had determined the species from specimens in the Bagnall collection reared from a puparium of Stenopteryx found in a house martin's nest in England and that he had seen specimens of the species from various points in Europe, South Africa, Australia, Palestine, and Korea. ${ }^{1}$ Timberlake has

${ }^{1}$ Doctor Waterston's records and conclusions as to synonymy are published here at his own suggestion. 
recorded the species from Hawaii. The National Collection shows that it occurs from New Jersey and North Carolina to California in North America. Apparently the species is nearly cosmopolitan.

Kurdjumov placed Boheman's species in the genus Lariophagus Crawford but stated that it was a form transitional to Mormoniella. His conclusion was based on specimens determined by Gustav Mayr. Kurdjumov noted some variation in these specimens as regards the development of the occipital carina. In all of the many specimens of the species that have come under my notice this carina is present though varying to some extent in its development.

Mormoniella is very similar to Lariophagus but the two genera may be separated by the following dichotomy:

Occiput with a carinate margin; funicle joints in female all broader than long; parapsidal grooves sharply defined on anterior two-thirds of mesoscutum; scutellum with a fine but more or less distinct cross furrow before the apex; propodeum about two-thirds as long as scutellum, terminating in a distinct short neck, without a transverse carina, the lateral folds distinct and a delicate median longitudinal carina usually present; head, mesoscutum, and scutellum with a shallow reticulate-punctate sculpture and shining

Mormoniella Ashmead.

Occiput entirely immargined; funicle joints not all broader than long; parapsidal grooves very weakly impressed at anterior angles of mesoscutum; scutellum without a cross furrow; propodeum less than half as long as scutellum, without a neck, with distinct transverse and median longitudinal carinae, the lateral folds distinct; head, mesoscutum and scutellum with fine deep punctation, opaque.......................... Lariophagus Crawford.

CECIDOSTIBA ACUTUS (Provancher)

Dinotus acutus Provancher, Add. Faun. Can. Hym., 1887, p. 201. Cecidostiba ashmeadi Crawford, Proc. U. S. Nat. Mus., vol. 43, 1912, p. 170.

A specimen agreeing with Provancher's description in every respect and said to have been reared from Polygraphus rufipennis in the province of New Brunswick, Canada, was recently received from $\mathrm{H}$. L. Viereck. This specimen was compared with the type of Cecidostiba ashmeadi Crawford which was described from specimens reared from the the same host species at Morgantown, West Virginia, and found to agree.

\section{Family EURYTOMIDAE}

\section{NEORILEYA MERIDIONALIS, new species}

Similar to the male of $N$. flavipes Ashmead but readily distinguished by the narrower face and the absence of any large punctures on the last visible tergite. Differs from the description of albipes Girault in lacking any trace of a fuscous spot appended from the stigma and by the absence of any median carina on the second tergite.

Male.-Length $2 \mathrm{~mm}$. Head as broad as thorax, viewed from above approximately two and one-half times as broad as long at 
the middle, concave behind, temples rounded; frons, vertex, and temples coarsely rugoso-punctate, occiput more finely rugose; ocelli in an obtuse triangle, the lateral ocelli about their own diameter from the eye-margin; head viewed from in front somewhat broader than long and subtriangular; eyes rather large, nearest each other at insertion of antennae; face and cheeks with strong striae converging at clypeus and covered with long white pile, the face not broad, the distance between eye margins at insertion of antennae much less than distance from antennae to apex of clypeus; cheeks strongly carinately margined behind and sculptured like the vertex; antennae inserted distinctly above the middle of front, the antennal depression short and not deep; antennae 13-jointed; scape cylindrical or nearly so, about four or five times as long as thick; pedicel pyriform, a little longer than broad; one very inconspicuous ringjoint: fourth antennal joint also very short, ringlike but distinctly broader than the third and three or four times as broad as long; fifth to tenth subequal and each slightly longer than broad; club 3 -jointed, conic ovate, not or scarcely broader than the last funicle joint, and about equal in length to the three preceding funicle joints; thorax strongly gibbose, uniformly umbilicately punctate and clothed with moderately long pale hairs on pronotum, mesoscutum, axillae and scutellum; the surface between the punctures finely shagreened; dorsal portion of pronotum about three times as broad as long at the middle, the posterior margin slightly arcuate; mesoscutum about one and one-half times as long as pronotum, the parapsidal grooves complete but shallow; scutellum about as long as mesoscutum; propodeum very coarsely reticulate-rugose, the spiracles large and much longer than broad; mesopleura longitudinally striated below and along the anterior margin, finely granular above, the posterior portion more shining and with two or three irregularly formed areas or reticulations; metapleura rugoso-punctate; coxae outwardly all finely shagreened; hind tibiae with two subequal spurs, the hind basitarsis nearly as long as four following joints; forewing irregularly and sparsely ciliated behind the submarginal vein, more densely and uniformly ciliated beyond, the costal cell also sparsely ciliated; marginal vein less than half as long as submarginal, about one-third longer than stigmal, and very slightly shorter than postmarginal; abdomen about as long and as broad as thorax, broadly ovate, broadest beyond the middle, narrowed at base, broadly rounded at apex; first tergite subtriangular, nearly twice as broad at apex as long down the middle; second tergite less than half as long as first, its posterior margin weakly arcuately emarginate; third the largest tergite, a little longer than first and second together; fourth about equal to the second; fifth very short; sixth about as long as fourth; seventh, except its margin, apparently concealed beneath the sixth; 
all tergites uniformly finely shagreened and dull, the fourth to sixth much more conspicuously hairy than the preceding, the sixth entirely without the coarse punctures present in flavipes Ashmead. Head, antennal flagellum, thorax, abdomen, and all coxae black; scape, pedicel, tegulae and all legs, except their coxae, pale testaceous; wings hyaline, venation dark brown; cilia of wings brownish, hairs of body silvery white.

Female unknown.

Type locality.--Sixola Valley, Limon, Costa Rica.

Type.-Cat. No. 29441, U.S.N.M.

Described from seven male specimens (one type) sent in for determination by F. R. Swift with the statement that they were parasitic in the eggs of Chlorocoris atrispinus Stal.

\section{Family EUPELMIDAE}

\section{Genus ENCYRTASPIS Ashmead}

Encyrtaspis Ashmead, Mem. Carnegie Mus. vol. 1, 1900, pp. 290, 492.

The description of this genus by Ashmead is to some extent inaccurate and excludes the new species described below which is certainly closely related to the genotype. A redescription seems desirable.

Female.-Head viewed from above transverse, as wide as the thorax or nearly so; occiput moderately concave and immargined; posterior orbits rather narrow; ocelli not far from the eye-margin, arranged in a slightly obtuse triangle; viewed from in front the head is as long as broad or longer than broad; antennae inserted distinctly below the ventral margins of eyes, broadly separated at base; scrobes consisting of a rounded shallow depression which is poorly defined; eyes rather large, faintly hairy, more or less convergent above; antennae 13-jointed; scape reaching to front ocellus, slightly curved; flagellum gradually increasing in thickness from pedicel to club; club obliquely truncate; mesoscutum trilobed, more or less depressed in the middle posteriorly, the lateral lobes either carinate or noncarinate posteriorly; axillae distinctly separated; scutellum convex, rounded behind, with a prominent median longitudinal crest of stiff black bristles; marginal and submarginal veins subequal, stigmal moderately long and subequal to the postmarginal or a little longer; forewing with a broad transverse band embracing most of the submarginal vein devoid of cilia, a small area at extreme base and the whole disk of wing beyond the apex of submarginal densely ciliated and with a dark fuscous cloud covering the whole area behind the marginal and postmarginal vein; front femora slightly swollen; middle tarsi swollen and distinctly spined beneath; hind femora not swollen, their tibiae 
compressed with a pale sharp carinate margin posteriorly, and bicalcarate; abdomen about as long as head and thorax combined, broadest near apex, dorsal segments 4 and 5 always emarginate medially and segments 2 and 3 sometimes emarginate, the last ventral segment more or less prominent, ovipositor exserted.

Male.-Resembles the male of Anastatus but may be distinguished by the shorter postmarginal vein. Antennae 11-jointed; scape short, third antennal joint ringlike, funicle joints cylindrical, thicker than the pedicel, the club apparently solid and a little more slender than the funicle joints; scrobes deeper than in the female, extending upward nearly to front ocellus; eyes densely hairy, nearly circular; mandibles 3-dentate; mesoscutum not depressed, parapsidal grooves delicately impressed and complete; scutellum rounded behind, convex; propodeum with a delicate median carina; wings without a cloud; postmarginal vein a little longer than stigmal; middle tarsi not swollen, the tibial spur long and slender; hind tibiae compressed, clubshaped; abdomen not longer than the thorax, subelliptical. Body color metallic.

Redescribed from the type of $E$. brasiliensis Ashmead, a cotype of E. proximus da Costa Lima and the types of the new species described below. This genus is probably closest related to Lecaniobius Ashmead, but is readily distinguished by the shape of the head and the shallow, poorly defined, antennal depression. The hind tibiae and other characters ally it also w ith Metapelma Westwood from which it is readily separated by the crest of hairs on the scutellum, the separated axillae, and the proportionally much longer marginal and much shorter postmarginal veins.

KEY TO THE SPECIES OF ENCYRTASPIS. FEMALES

1. Ovipositor sheaths slightly longer than the whole body, with a broad whitish band before the apex and a pale line beneath from base to the union with the band brasiliensis Ashmead.

Ovipositor sheaths not as long as the body.

2. Mesoscutum bronzy black, not deeply concave at posterior middle, the lateral lobes not sharply carinate; axillae metallic; propodeum and hind coxae more or less metallic; ovipositor sheaths with a yellowish band

proximus da Costa Lima.

Mesocutum uniformly rufo-testaceous, deeply concave at posterior middle, the lateral lobes high and sharply carinate posteriorly; axillae rufo-testaceous as are also the propodeum and hind coxae; ovipositor sheaths uniformly testaceous semirufus, new species.

ENCYRTASPIS SEMIRUFUS, new species

Female.-Length, $3 \mathrm{~mm}$. Head nearly uniformly shagreened; viewed from in front appearing a little longer than broad, the cheeks rather long; eyes strongly diverging below, more than twice as far apart at lower extremity as at vertex; viewed from the side the head 
thin, temples narrow with the posterior orbit depressed and forming a groove along the eye-margin which is covered with a dense silvery pubescence; profile above the antennae straight, below antennae slightly receding; antennae more than twice as long as the head, the flagellum increasing slightly in thickness from base to near apex, scape subcylindrical, pedicel about one and one-half times the length of third antennal joint, fourth joint twice as long as third, fifth to tenth joints successively decreasing in length, the tenth very slightly longer than broad; club a little longer than the two preceding funicle joints and not a great deal thicker, 3-jointed, the joints subequal in length; anterior lobe and outer face of lateral lobe of the mesoseutum with fine granular sculpture, the lateral lobes on posterior half sharply carinate above; concave posterior portion of mesoscutum smooth and polished or nearly so; scutellum convex, rounded behind, opaquely sculptured, with a conspicuous tuft of black bristles; front femora somewhat expanded posteriorly, broadest near apex; front tibiae somewhat compressed; middle tibiae slightly compressed at apex with a group of four or five short black spines at the apex, the first three joints of their tarsi with a double row of short spines beneath; hind tibiae compressed with a carinate expansion or flange along the posterior margin extending from base to apex and about one-third the breadth of tibiae; abdomen ovate, as broad or somewhat broader than thorax, as long as head and thorax, distinctly shagreened, the fourth and fifth tergites emarginate medially, the second and third with the hind margin straight, ovipositor about two-thirds as long as the abdomen. Head and thorax, scape, all coxae and femora, basal one-third of abdomen more or less, and the ovipositor sheath rufotestaceous; antennal flagellum, maxillary palpi, eyes, broad median stripe on the mesosternum, and apical two-thirds or more of the abdomen blảck; front tibiae and tarsi, middle tibiae and hind tibiae fusco-testaceous, the hind tibiae darker than the others; middle tarsi pale yellowish above, the spines beneath and apical joint black; hind basitarsis and apical joint black, the second to fourth joints pale yellow; forewing from base to apex of submarginal hyaline, from base of marginal to apex of postmarginal veins covered by a broad fuscous band, beyond apex of venation subhyaline.

Male.-Length, $1.75 \mathrm{~mm}$. Head and thorax very weakly shagreened, propodeum smooth, abdomen faintly shagreened; scape about twice as long as broad; pedicel a little longer than broad; ring-joint small, transverse; first funicle joint slightly the longest, about one and one-half times as long as thick; last funicle joint subquadrate; club conical and about as long as the two preceding joints. Body color bluish-black with a metallic sheen; antennae dull black, the scape slightly metallic; mandibles brownish; legs concolorous with the body; the fore and median knees and their tibiae at apex, a 
narrow band at extreme base of hind tibiae and all tarsi white; the apical joint of all tarsi dark; wings entirely hyaline, the venation pale.

Type locality.-Macon, Georgia.

Type-Cat. No. 29442, U.S.N.M.

Type female reared from Laspeyresia molesta Busck, August 1, 1924, by Roy Rogers and sent to the Bureau of Entomology for identification by J. D. More. A paratype female and three males, including the allotype received from $\mathrm{H}$. K. Plank under Quaintance No. 24035 and said to have been parasitic upon a leaf skeletonizer at New Orleans, Louisiana, reared July 13, 1923. A third female paratype, which is without the head, is from Victoria, Texas, collected by J. D. Mitchell in Spanish moss, March 30, 1908.

\section{ANASTATOIDEA, new genus}

Intermediate between Metapelma Westwood and Anastatus Motschulsky, but may be distinguished from Metapelma by the distinctly impressed, more or less semicircular and delicately margined scrobes; separated axillae; shorter postmarginal vein; truncate apex of abdomen; shorter middle tibial spur; and the compressed and expanded apical joint of maxillary palpus. Distinguished from Anastatus by the strongly exserted ovipositor; the compressed hind tibiae and basitarsus which are very similar to those of Metapelma; the hairy eyes and the absence of a transverse hyaline band on the forewing.

Female.-Similar in habitus to Anastatus. Head viewed from in front about as broad as high; scrobes distinctly but not deeply impressed, rounded above and margined by a delicate but distinct carina; antennae 13-jointed, inserted near mouth, rather long, and not strongly clavate; scape cylindrical, moderately long and slightly curved; club not large, its apex slightly obliquely truncate; eyes large and distinctly hairy; vertex rather narrow; lateral ocelli close to the eye-margins; front ocellus far above the scrobes; maxillary palpi 4-jointed, the apical joint broad and compressed; labial palpi 3 -jointed, the apical joint thickened; head viewed from above strongly transverse; thorax ovate, robust; prothorax subtriangular; mesoscutum depressed medially, the lateral lobes prominent, the median lobe moderately convex; axillae distinctly separated by base of scutellum; propodeum short; wings hyaline and bare at base, fuscous and densely ciliated beyond apex of submarginal vein; postmarginal vein much shorter than marginal, stigmal shorter than postmarginal; front femora not greatly swollen; middle tibial spur not as long as basitarsus, the latter with a double row of strong spines beneath; hind tibiae bicalcarate, compressed into a moderately narrow flange behind, the flange extending from very near base to apex of tibiae and bordered with white; hind basitarsus compressed into a narrow 
flange behind; abdomen not longer than thorax, sessile, its apex truncate or broadly rounded; ovipositor strongly exserted. Male unknown.

Type of the genus.-Anastaioidea brachartonae, new species.

ANASTATOIDEA BRACHARTONAE, new specieg

Plate 1 , fig. 3

Female.-Length $4 \mathrm{~mm}$. Head, in front view, broader above than below, squarely truncate at the mouth; cheeks equal to about half the length of scape; face shagreened and clothed with short appressed scalelike hairs; the cheeks with a beard of moderately long black bristles; scrobicular depression finely shagreened; frons nearly twice as wide at upper margin of scrobe as at the lateral ocelli, very finely shagreened and clothed with fine grayish hairs, its lateral margins with a row of erect grayish hairs; ocelli in a nearly equilateral triangle, the front ocellus about five times its own diameter above the margin of scrobe, lateral ocelli touching the eye-margins; vertex clothed with black bristles; temples and occiput with fine rugulose sculpture and short silvery pubescence; antennal pedicel approximately twice as long as the third antennal joint which is longer than broad; fourth antennal joint more than twice as long as broad, the tenth subquadrate; club a little longer than the two preceding funicle joints; middle lobe of mesoscutum uniformly densely punctate and opaque, lateral lobes much more weakly and finely sculptured and clothed with short pale pubescence; scutellum and axillae punctate like the praescutum but the punctures slightly coarser, the vertical margins of scutellum weakly reticulated and shining; propodeum weakly shagreened at the sides, smooth medially; pleura with fine longitudinal lineolation; front femora moderately stout, their tibiae somewhat compressed; middle tibiae with a group of about 12 short black spines at apex on the anterior side, the tibial spur about two-thirds as long as basitarsus, the first, second and third tarsal joints each with a double row of short spines beneath; hind legs long, their femora compressed, but not expanded, their tibiae with two unequal spurs, the flangelike posterior margin about as broad in its broadest portion as the noncompressed portion of tibiae and nearly uniform in width throughout, except that it is slightly narrowed basally; hind basitarsus about as long as the four following joints together, compressed into a flange behind, the flange about equal in width to the noncompressed portion; forewing extending to or slightly beyond the apex of abdomen; postmarginal vein about half as long as marginal; stigmal about half the length of postmarginal; costal cell with about three closely set rows of fine cilia near the vein and extending from base to near apex of cell; basal cell bare; remainder of wing densely ciliated, the ciliated area abruptly truncated basally, the cilia behind the marginal and 
stigmal veins flattened and scalelike, beyond the apex of stigmal vein normal; hind wing less densely ciliated, the cilia not scalelike, basal cell bare; abdomen about as long as thorax, the first to third tergites more or less distinctly emarginate medially, first to fourth bare and nearly smooth dorsally but with the sides sparsely clothed with whitish pile and distinctly finely shagreened; segments beyond the fourth with longer and more conspicuous pale hairs and finely sculptured; ovipositor exserted a little more than the length of abdomen. General color blackish; scape and mandibles dark reddish testaceous, pedicel slightly bluish, flagellum black, the oblique side of club pale yellowish; face below antennae coppery mixed with purplish; scrobicular area and frons black; temples dull coppery with a narrow strip along the eye margin metallic green; dorsum of thorax mostly aeneous black, the concave posterior portion of mesoscutum marked with bluish-green and coppery; mesopleura with green and purple tints in some lights; prosternum metallic green; mesosternum mostly black but with some metallic reflections; front and middle coxae mostly testaceous, the front femora and tibiae mostly testaceous beneath and dark brownish above, front tarsi brownish black; middle femora and tibiae mostly dark brown or blackish, but with the flattened anterior margin of femora whitish and the apex of tibiae testaceous; first and second joints of middle tarsi white above, the apical three joints blackish; hind legs black except that the apical half of femora outwardly are more or less testaceous and the hind margin of tibiae from near base to apex are narrowly margined with white; forewings hyaline at base, fuscous from the swollen apex of submarginal vein outwardly but becoming less strongly so apically, venation pale; abdomen black with a testaceous basal spot dorsally; ovipositor sheaths black.

Type locality.-Central Java.

Type-Cat. No. 29444, U.S.N.M.

Described from four females. The holotype and two paratype specimens were received by the writer from C. T. Brues of the Bussey Institution to whom they had been sent for determination by S. Leefmans of Buitenzorg, Java. These specimens are labeled "E-VII-EE." A letter from Doctor Leefmans says that the species has been reared from Brachartona catoxantha Hampson material both as a primary and as a secondary parasite. As a primary parasite it is said to be ectoparasitic upon the prepupal larvae or the pupae of Brachartona. As a secondary it has emerged from the puparia of Degeeria albiceps Macquart and Ptychomyia remota Aldrich and from cocoons of Apanteles species and an unidentified Ichneumonid. Boroboedoer, Dogatien, Salaman, Krogosingan, Kloemprit, Pakisredjo, Redjeso, Sleman, and Poendoeng are mentioned by Leefmans as localities in which the species has been taken. The exact locality and 
host relations for the holotype specimens and two paratypes mentioned are unknown to the writer. A third paratype received direct from Leefmans is said to have been reared from Apanteles, species at Dogatien. This specimen is much smaller than the holotype (length $2.4 \mathrm{~mm}$.) but otherwise identical.

The following already described species apparently are congeneric with the above and should be transferred to Anastatoidea:

Metapelma columbi Girault, Ins. Ins. Mens., vol. 11, 1923, p. 97.

Metapelma longfellowi Girault, Ins. Ins. Mens., vol. 11, 1923, p. 99.

Metapelma superba Dodd, Trans. Roy. Soc. S. Australia, vol. 41, 1917, p. 357.

The four known species belonging to the genus may be separated by the following key, which in the case of the Girault and Dodd species is based upon the original descriptions:

KEY TO THE SPECIES OF ANASTATOIDEA GAHAN

1. "Scutum with a median ridge from whose sides, like tree branches, silvery hairs proceed." Ovipositor as long as the body .......... columbi Girault.

Median lobe of mesoseutum not as above; ovipositor usually not as long as the body . . _ _ _ _ _

2. Ovipositor with a whitish band before apex; forewing with a large bristle at the posterior margin half way between base of wing and the beginning of discal ciliation; discal cilia behind marginal vein stout but not scalelike

longfellowi Girault.

Ovipositor not banded; forewing without such a bristle; discal cilia behind marginal vein scalelike_._.

3. Lower half of face transversely lineolated; lateral lobes of mesocutum transversely lineolated; legs deep rufous, lightly washed with metallic especially strong on the hind femora; hind coxae purplish. - superba Dodd.

Lower half of face not transversely lineolated but finely reticulate-punctate or shagreened; lateral lobes of mesoscutum not transversely lineolated but very finely shagreened; legs mostly very dark brown or black, the anterior and median coxae mostly rufo-testaceous, their femora and tibiae varied with testaceous and the hind femora outwardly toward apex marked with testaceous

brachartonae, new species.

\section{Family ENCYRTIDAE}

\section{OOENCYRTUS LATISCAPUS, new species}

Generically this species seems to agree fully as well with the description of Xesmatia Timberlake as with Ooencyrtus Ashmead. No specimens of the genotype of Xesmatia are available for study, but if, as seems probable, the present species is congeneric with $X$. favipes Timberlake, then Xesmatia is, in my opinion, hardly worthy of retention. The principal characters pointed out in the original description of Xesmatia to distinguish the two genera appear to be that in Ooencyrtus the mandibles have an acute ventral tooth and a broadly truncate inner one, and the surface of the body has a shagreened appearance while in Xesmatia the mandibles are said to be three-toothed, the middle tooth the largest, the upper and lower teeth both rather obscure giving the appearance of a broad apex 
with a single median tooth, and the surface of head and body is smoother and shinier, the scutellum entirely smooth and polished. In the present species the mandibles are very nearly as in Xesmatia, while the mesoscutum and scutellum are distinctly shagreened as in Ooencyrtus. While representing a very distinct species in the genus the agreement with other species of Ooencyrtus in the essential generic characters as well as in its habits is such that I believe it is properly placed in that genus.

Differs from all other species in the genus known to the writer by the expanded scape as well as by the more strongly clavate and varicolored flagellum (fig. 1).

Female.-Length $0.7 \mathrm{~mm}$. Head as broad as thorax; frontovertex moderately narrow, a little more than twice as long as broad, finely reticulate-punctate and somewhat shining; eyes weakly pilose, diverging below; ocelli small, in a nearly equilateral triangle; mandibles subtruncate at apex, with a very weak ventral tooth, the middle of apical margin very slightly more prominent than either

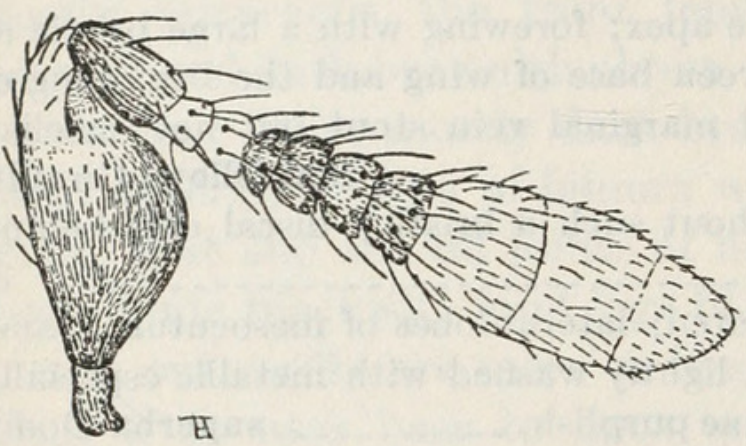

Fig. 1.-Ooencyrtus latiscapus Gahan, antenNa OF FEMALE the ventral or inner angles but not forming a distinct tooth; antennal scape expanded beneath, subtriangular, about twice as long as broad and broadest near or a little below the middle; pedicel twice as long as thick at apex; flagellum strongly clavate, the club much broader than the funicle and as long as funicle; first funicle joint a little longer than broad and distinctly much narrower than the pedicel, second to sixth inclusive broader than long and successively increasing in width, the sixth about as broad as apex of pedicel; funicle joints hairy, the hairs arranged in a single more or less regular whorl near the apex of segment and about twice as long as the segment; club nearly twice as broad as sixth funicle joint, elongate oval and compact, the dividing sutures distinct but not deep, and the surface of all three segments evenly covered with hairs which are much shorter and finer than those of the funicle; mesoscutum about twice as broad as long, distinctly finely reticulate-punctate or shagreened, somewhat shining, and weakly pilose; scutellum similar but a little more finely sculptured and subopaque above, smooth and polished apically; propodeum very short and finely shagreened; pleura sculptured and subopaque; stigmal vein a little longer than marginal, very slender at base, the stigmal knob normal; marginal longer than broad; disk of wing sparsely ciliated basad of hairless streak, uniformly and more densely ciliated beyond, the hairless streak moderately broad, open behind, a single row consisting of about eight 
coarser cilia extending obliquely inward and backward from the marginal vein and partially dividing the hairless streak into anterior and posterior areas; abdomen (in dead specimens) very short and subtriangular, about half as long as thorax, finely shagreened above, the vibrissae rather short; ovipositor not exserted. Apex of scape, first and second flagellar joints and entire club pale yellow or nearly white, rest of antenna black; head dull black, the frons with a very faint metallic tinge; thorax mostly dull black but with the mesoseutum metallic greenish and the scutellum bronze, the polished portion of latter with more metallic greenish reflections; abdomen black with slight metallic tinge above; leg black; all trochanters, narrow basal band and broader apical band on all tibiae and all tarsi pale yellowish; wings hyaline or with only a very faint fuscous tinge, venation dark brown.

\section{Male unknown.}

Type locality.-Sixola Valley, Province of Limon, Costa Rica.

Type.-Cat. No. 29443, U.S.N.M.

Described from 12 female specimens received from F. R. Swift, Almirante, Panama Republic, and reared by him from eggs of Hemiceras rava collected in Sixola Valley, Costa Rica.

\section{OOENCYRTUS SUBMETALLICUS (Howard)}

Encyrtus submetallicus How ARD, Journ. Linn. Soc. Lond. Zool., vol. 26, 1896, p. 151.

Syrphophagus submetalliçs Ashmead, Proc. U. S. Nat. Mus., vol. 22, 1900, p. 398.

The type of this species should be in the British Museum. A paratype specimen in the United States National Museum has been mounted on a slide by Girault and is in poor condition. In the collection, however, are nine female specimens determined by Girault as Encyrtus submetallicus after comparison with this paratype. These were reared from eggs of the hemipteron, Nezara viridula, collected on the island of St. Vincent, West Indies, and were sent in by F. Watts. They agree with what is left of the paratype as well as with Howard's description and seem to be correctly determined.

The species belongs in the genus Ooencyrtus Ashmead. In color markings it is quite similar to moneilemae Gahan but differs from that species by having the frons distinctly narrower, the mesoscutum and scutellum more distinctly sculptured and the forewings somewhat narrower. It may be distinguished from the other American species by the entirely pale testaceous legs.

$28453-27 \dagger-3$ 


\section{APHIDENCYRTUS INQUISITOR (Howard)}

Encyrtus inquisitor HowARD, Rept. U. S. Dept. Agri. 1880, p. 367, pl. 24, fig. 1. Encyrtus schizoneurae Ashme ad, Trans. Amer. Ent. Soc., vol. 12, 1885, Proc. p. 16. Encyrtus aphidiphagus AshmedD, U. S. Dept. Agri., Div. Ent. Bull. 4, 1887, p. 14.

Encyrtus megourae Ashmead, U. S. Dept. Agri., Div. Ent. Bull. 14, 1887, p, 19. Encyrtus websteri How ARD, Insect Life, vol. 2, 1890, p. 247, fig. 53.

Zarhopalus inquisitor (Howard) Ashmead, Proc. U. S. Nat. Mus., vol. 22, 1900, p. 406.

A phidencyrtus schizoneurae (Ashmead), aphidiphagus (Ashmead), megourae (Ashmead), and websteri (Howard) Ashmead, Proc. U. S. Nat. Mus., vol. 22, 1900, pp. 399 and 400 .

Aphidencyrtus aphidiphagus (Ashmead) GaHan, Proc. Ent. Soc. Wash., vol. 25, 1923, p. 195.

Types of all the above cited species of Aphidencyrtus are in the United States National Museum and a careful comparison of these types in conjunction with a study of additional material has convinced the writer that they are all one species. The slight differences pointed out by Girault ${ }^{2}$ for separation of the species are variable and not of specific value. In the Girault article the statement is made that (Encyrtus) Aphidencyrtus siphonophorae Ashmead is the same as $A$. aphidiphagus Ashmead, but, as the writer has already shown, ${ }^{3}$ the type of (Encyrtus) Aphidencyrtus siphonophorae Ashmead is in fact a Pachyneuron. Girault's statement was based upon specimens wrongly determined by Ashmead and which Girault mistook for the types.

Aphidencyrtus inquisitor seems to agree very well with the description of Aphidencyrtus aphidivorus (Mayr) as treated by Mercet $^{4}$ and may be the same species. Unfortunately, no specimens of the European species are at hand for comparison.

Types of (Encyrtus) Aphidencyrtus lachni (Ashmead) seem to be missing from the national collection. The description indicates that it is quite distinct from inquisitor.

The type of (Blastothrix) Aphidencyrtus rosae (Ashmead) is partly missing but enough remains to show that Howard ${ }^{5}$ was correct in placing this name in synonymy with Aphelinus mali Haldeman.

\section{COCCIDENCYRTUS OCHRACEIPES, new species}

Differs from $C$. ensifer Howard and the other species of the genus in that the antennae and legs, including all coxae, are pale yellow.

Female.-Length $0.62 \mathrm{~mm}$. Head as broad as thorax; frons moderately broad, distinctly reticulate-punctate, slightly shining; ocelli in a nearly equilateral triangle; antennal scape fusiform; pedicel about twice as long as broad at apex; joints one to three of the funicle 
small, about as long as broad; joints four to six longer than broad, the whole funicle rather slender but gradually increasing in thickness from base to apex; club nearly as long as the funicle, 3-jointed, elongate-ovate, nearly twice as broad as the last funicle joint; mandibles both distinctly tridentate; thorax as broad as long; mesoscutum about twice as broad as long, shallowly but distinctly reticulate-punctate, distinctly shining; scutellum about as long as mesoscutum, very finely sculptured and opaque, axillae sculptured like scutellum; propodeum very short, without definite sculpture; forewings a little longer than the whole body, rather broad; submarginal vein with six or seven evenly spaced long bristles dorsally; disk of wing rather densely and êvenly ciliated all over except for a subtriangular speculum behind the marginal vein; abdomen not longer than the thorax and as broad as thorax, the tip of ovipositor exposed. General color metallic black, the frons with strong brassy and violaceous tints and the mesoscutum metallic green; antennae and legs pale yellow, all coxae and femora nearly white; abdomen dorsally and ventrally yellowish at basal middle, with broad lateral and apical margins brownish-black; wings hyaline.

Type locality.-Ithaca, New York., in greenhouse.

Type.-Cat. No. 29460, U.S.N.M.

Host.-Diaspis boisduvallii Signoret.

Five females reared from the above-named scale insect on Cattleya species by Miss Grace H. Griswold, of Cornell University. Holotype mounted in balsam on a slide. Four paratypes mounted on card points. Male unknown.

\section{Family APHELINIDAE}

\section{ENCARSIA MERTTORIA, new species}

Belongs to the species group having the middle tarsi 4-jointed. The species is easily distinguished from others of the group by the much paler and nearly uniform color of the female. The male may be distinguished by the fact that the head and thorax are mostly yellow and the abdomen dark brownish.

Female.-Length $0.6 \mathrm{~mm}$. Antennae slightly shorter than the insect; scape cylindrical, narrowed apically; pedicel one and one-half times as long as broad; first funicle joint four-fifths as long as the pedicel and about three-fourths as broad as long; second joint one and one-half times the length of first; third a trifle longer than the second; fourth equal to the second; two joints of the club each slightly longer than the four th funicle joint and somewhat thicker, the apical joint conical; head as broad as the thorax; the face broad and apparently smooth; upper part of frons and the vertex distinctly transversely wrinkled; eyes bare; posterior ocelli nearer to each other than to the ey e-margins; thorax as broad as long, mesoscutum and scutellum very faintly if at all sculptured; axillae appearing granularly sculptured; forewings 
ample, marginal and submarginal veins nearly equal, submarginal with two prominent bristles dorsally, discal cilia nearly uniform from base of marginal vein to apex of wings and not quite as close together as in formosa Gahan; longest marginal cilia about one-third as long as the width of wing; middle tarsi 4 -jointed, its basitarsus only a little longer than the apical joint; hind basitarsus about twice as long as the apical joint; abdomen subequal to the thorax or a little longer, the ovipositor barely visible at apex. Color nearly uniformly pale yellow throughout, the vertex tinged with orange yellow; ocelli pale red; eyes black; antennae and legs pale; wings perfectly hyaline, venation pale.

Male.-Similar to the female but differing somewhat in color and antennal characters. Antenna 8-jointed; pedicel not longer than broad; flagellar joints subequal and each nearly three times as long as thick. Head above orange yellow with a dusky transverse band on occiput, the face and cheeks pale yellow; pronotum, anterior margin of praescutum and axillae dark brownish; rest of thorax orange yellowish; abdomen blackish brown with a narrow transverse band at base and the extreme apex slightly paler. The axillae appear to be somewhat more distinctly granular than in the female and the mesoscutum and scutellum apparently have some rather large reticulations.

Type locality.-Miami Beach, Florida.

Type.-Cat. No. 29445, U.S.N.M.

Host.-Trialeurodes floridensis Quaintance.

Ten females and nine males mounted in balsam on five slides. Reared from the above-mentioned host on avocado, May 12, 1924 by G. F. Moznette.

\section{ENCARSIA BASICINCTA, new species}

Belongs to the group having all tarsi distinctly 5-jointed, and resembles pergandiella Howard but may be distinguished from that species by the shorter first funicle joint, as well as by the much paler general color and the presence of a conspicuous blackish or fuscous band at the base of the abdomen.

Female.-Length $0.57 \mathrm{~mm}$. Antennae not quite as long as body, very weakly clavate; pedicel ovoid, about one and one-half times as long as thick; first funicle joint shorter and narrower than the pedicel, about one and one-half times as long as thick; second distinctly longer than the first, about equal in length to the pedicel; third to sixth subequal in length and each approximately one and one-half times the second; the last two joints are somewhat more closely joined together than the preceding but are no thicker than the fourth joint and only slightly thicker than the first; flagellar joints with sparse inconspicuous hairs; mandibles tridentate; vertex granularly rugulose; mesoscutum and scutellum also granular, the paired setae all pale and very inconspicuous; forewings rather small $(0.47 \mathrm{~mm}$. 
in length by 0.14 in breadth) the marginal fringe very nearly equal to the breadth of wing; discal cilia absent from that portion of the wing behind the submarginal vein and also from a rounded area embracing the stigmal vein; the rest of wing surface mostly ciliated but with a narrow border around the outer portion of wing nearly or quite bare save for a single row along the margin; submarginal vein with two bristles; hind wing with the marginal cilia about twice as long as the breadth of wing, the discal ciliation consisting of a row along the anterior margin from the apex of venation to the apex of wing, a more or less imperfect row along the posterior margin from near base to apex, and a short row between these two which does not reach the apex of wing; all tarsi distinctly 5-jointed; abdomen as long as the thorax, rounded apically, the ovipositor exserted approximately one-fifth the length of abdomen. General color very pale yellow, almost white; the occiput above, borders of mouth narrowly, pronotum and narrow anterior border of mesonotum, spot on axillae, propodeum, a broad transverse basal band embracing approximately one-third of the abdomen, and a spot on each side embracing the vibrissal plates, distinctly fuscous; antennae slightly dusky, legs entirely pale.

Type locality.-San Juan, Porto Rico.

Cotypes.-Cat. No. 29446, U.S.N.M.

Host.-Aleurothrixus floccosus (Maskell)

Described from eight females reared by H. L. Dozier, January 3, 1925 , and all mounted in balsam on a single slide.

PROSPALTELLA BELLA, new species

A species superficially resembling very closely $P$. perniciosi Tower, from which it is distinguished by having the first funicle joint distinctly longer than broad, the third funicle joint also more than twice as long as broad and the forewing without a dusky band behind the marginal. Also resembles $P$. aurantii Howard, but may be distinguished by the above-mentioned antennal characters. It is very similar to female specimens in the National collection from Italy said to represent $P$. conjugata Masi, but differs by having the second funicle joint as long or very slightly longer than the third and the head entirely black. Differs from the description of conjugata also by having the antennae 8-jointed in the male instead of 7 -jointed.

Female.-Length $0.65 \mathrm{~mm}$. Antennae rather slender, the club distinct and a little thicker than the funicle; scape slender, cylindrical; pedicel a little more than one and one-half times as long as thick; first funicle joint very nearly twice as long as broad and about threefourths as long as the pedicel; second funicle joint one and one-half 
times as long as the first and three times as long as thick; third joint equal to the second in length and very slightly thicker; club with three distinct joints, the first and second each subequal to the third funicle joint in length and approximately twice as long as broad, the third a little longer than the others and conical in shape. Head not quite as broad as thorax, apparently smooth; ocelli moderately large, placed in a slightly obtuse triangle; praescutum distinctly reticulated (under high power magnification); scutellum and axillae without definite sculpture, the former with a deep median longitudinal groove; wings ample, the longest marginal cilia of forewing very nearly equal to half the greatest width of wing, submarginal and marginal veins very nearly equal. Abdomen as broad as thorax and distinctly longer; ovipositor sometimes very slightly exserted. General color brownish black; head entirely, mesoscutum for the most part, axillae, metathorax, propodeum and abdomen brownish black; scutellum pale yellowish; narrow borders of praescutum along parapsidal grooves, scapulae, more or less of pleura, and to some extent the underside of the thorax yellow but darker than the scutellum; antennae and legs pale yellowish, the hind coxae brownish and the hind femora sometimes faintly dusky; wings hyaline, the venation dusky.

Male.-Length $0.6 \mathrm{~mm}$. Agrees with female except in antennal characters. Antennae nearly as long as the body, 8-jointed, scape slender, pedicel one and one-half times as long as broad at apex; first flagellar joint very nearly twice as long as the pedicel; second, third, fourth, and fifth joints subequal, about three times as long as broad and each very slightly longer than the first; apical joint conical and a little shorter than the preceding. Abdomen about equal to the thorax in length.

Type locality.-Agricultural College, Michigan.

Cotypes.-Cat. No. 29447, U.S.N.M.

Host.-Chionaspis pinifoliae (Fitch)

Described from 36 specimens, 19 females and 17 males, mounted in balsam on two slides, received from Prof. R. H. Pettit, of the Michigan Agricultural College, and said to have been reared June 28, 1924, from the above-mentioned pine leaf scale on Pinus strobus. According to Professor Pettit the parasite was very abundant.

\section{Prospaltella Ciliata, new species}

Resembles (Mimatomus) Prospaltella peltatus Cockerell in having the marginal fringe of forewing short, the longest marginal cilia being approximately one-sixth as long as the greatest width of wing, but differs from peltatus as well as all other species known to the writer by having the discal cilia behind the marginal vein more obviously longer and somewhat coarser than those toward apex of wing. The 
first funicle joint is a little longer than the second, and the antennal club is equal in length to the funicle. Also resembles Encarsia portoricensis Howard but differs by having the antennal club composed of three joints the last two of which are poorly separated, the marginal vein shorter than the submarginal, and the hind legs marked with black.

Female.-Length $0.9 \mathrm{~mm}$. Antennal pedicel rather thick, almost as broad as long; first funicle joint distinctly longer than pedicel and slightly longer than second funicle joint; third joint the shortest, fully twice as long as broad; club 3-jointed, not much thicker than the funicle, the joints subequal in length, the two apical joints indistinctly separated; vertex broad, the distance between the eyes at vertex being greater than the length of antennal club; lateral ocelli separated from the eye margin by at least the diameter of an ocellus; vertex transversely wrinkled, and with a transverse row of about 12 spines on the posterior margin separating it from the occiput; frons apparently, granularly sculptured and with numerous spines; eyes hairy. Praescutum and the scutellum apparently with fine reticulate sculpture; scutellum with four bristles, the posterior pair long and closer to each other than to the lateral angle of scutellum; forewings normal in size; marginal vein shorter than submarginal, the latter with two erect bristles; stigmal rather long, about one-third as long as marginal; disk of wing behind submarginal vein bare, except for a single row of cilia near the vein and extending from about the middle of vein to its apex; cilia covering the area behind marginal vein distinctly longer and coarser than those toward wing-apex; longest marginal cilia less than one-sixth as long as wing is broad; abdomen as long and about as broad as thorax, rounded apically, the ovipositor sheaths very sightly exserted; legs normal, tarsi all 5-jointed, middle tibial spur slender and as long as basitarsus; the basitarsus with several short thick spinelike bristles on the underside toward apex. Head and thorax mostly pale yellowish; the antennae and frons orange yellow; occiput, pronotum, anterior margin of praescutum, pleura for the most part, propodeum, and abdomen brownish black; legs mostly pale yellowish or whitish, the middle and hind coxae and basal half of hind femora blackish, and the hind tibiae stained with fuscous at base; wings hyaline with a transverse band behind the marginal vein very faintly fuscous.

Type locality.-San Juan, Porto Rico.

Type.-Cat. No. 29448, U.S.N.M.

Host.-Aleurodicus, undescribed species.

Described from a single balsam-mounted female reared by H.L. Dozier, January 10, 1925, from what Mr. Dozier considers an undescribed species of white-fly. 
COCCOPHAGUS GOSSYPARIAE, new species

Coccophagus gossypariae (Howard MS.) Herbert, U. S. Dept. Agr. Bull. No. 1223, 1925, p. 12.

Apparently close to scutellaris Dalman, but differs by having the scutellum entirely black. Readily distinguished from the other species known to the writer by the color of the legs.

F emale.-Length, $1.2 \mathrm{~mm}$. Antennae moderately long; first funicle joint distinctly longer than pedicel and very slightly longer than second funicle joint; second and third subequal or the third somewhat shorter, the latter one and one-half to two times as long as thick; club approximately equal in length to the second and third funicle joints combined, and slightly thicker than the funicle; frons strongly punctato-rugulose; cheeks distinctly reticulated. Thorax rather robust; mesoscutum, scutellum, and axillae weakly reticulated, subopaque or only slightly shining and sparsely clothed with fine hairs, the scutellar bristles weak, only the apical pair being conspicuous; propodeum nearly smooth; marginal and submarginal veins nearly equal; marginal cilia of forewings short; abdomen as long as thorax and nearly smooth. Head, thorax and abdomen blâck; antennae entirely blackish brown; vertex laterad of ocelli marked with a brownish spot; anterior legs entirely, median pair except coxae basally, posterior coxae at extreme apex, hind trochanters and their tibiae pale yellow; base of middle coxae, hind coxae except at apex, and hind femora black; tarsi more or less infuscated apically; wings hyaline, venation dark brown.

Type locality.-Ithaca, New York.

Type.-Cat. No. 29449, U.S.N.M.

Described from fifteen females received from Miss Grace Griswold, of Cornell University, said to have been reared from Gossyparia spuria at Ithaca, New York, and three females labelled "from Gossyparia ulmi, Bedford, Massachusetts, June 15, 1898." The three last mentioned specimens were found in the collection under the name "Coccophagus gossypariae Howard MS.," and this name has been adopted for the species.

The color of this species seems to be somewhat variable. In the three specimens from Massachusetts the whole frons and face is dark reddish brown instead of black as in the type. In some individuals the front coxae are slightly infuscated at base and the middle coxae mostly black; in others the middle as well as the front coxae are almost wholly pale and the hind coxae in large part also pale. In spite of these color differences they all seem to be the same species. 
To the list of synonyms of C. lecanii (Fitch) given by the writer ${ }^{6}$ should be added $C$. coccidis Girault and $C$. cowperi Girault. The types of coccidis which were reared from Coccus hesperidum (Linnaeus) at New Orleans, Louisiana, are merely slightly discolored specimens of lecanii, the discoloration probably due to abnormal conditions in the breeding cages in which they were reared.

The types of cowperi which were reared from Stictococcus gowdeyi Newstead, September 20, 1915, Nagunga, Uganda, Africa, by C. C. Gowdey, differ from typical lecanii only in that the wings appear to be very slightly more densely ciliated and very faintly dusky, while the fore and median femora are paler than in lecanii although slightly washed with fuscous. In the National collection are three specimens, agreeing in every way with the types of cowperi, reared from Saissetia oleae (Bernard) at Capetown, Scuth Africa, in May, 1910. Harold Compere, of the California Citrus Experiment Station, recently sent to the writer several specimens reared December 1, 1925, from Saissetia oleae taken at Capetown by E. W. Rust. The latter specimens agree with the types of cowperi in every way except that the legs are colored as in typical lecanii.

There seems to be no doubt that Girault's types and all of this material from Saissetia oleae are the same species and the differences between the wings of this African form and American representatives of lecanii are so slight that it is believed the African specimens represent merely a variation or at most a geographical race of $C$ lecanii (Fitch).

\section{PHYSCUS DIASPIDIS (Howard)}

Encarsia diaspidis Howard, U. S. Dept. Agr. Bur. Ent. Tech. Bull. 12, pt. 4, 1907 , p. 77.

Encarsia diaspidis Mercet, Trab. del. Mus. de Cien. Nat. de Madrid, No. 10, 1912, p. 155.

As indicated by Doctor Howard in his original description, this species is not an Encarsia. The writer is of the opinion, after examining the type, that it belongs in the genus Physcus where it differs from all of the other species known to the writer by having the first funicle joint in the female fully twice as long as pedicel and distinctly the longest of the funicle joints. The mesoscutum is closely set with rather coarse hairs and has a single pair of coarse setae at the posterior margin. On each half of the scutellum are from seven to ten stiff setae, its surface otherwise bare.

While the antennae of the female are 7 -jointed, those of the male are 8-jointed. The male scape is rather short and distinctly expanded beneath, about two and one-half times as long as broad; pedicel about as long as broad; first funicle joint distinctly thicker than the pedicel, about three times as long as thick and one and one-half times as long as the second; second and following joints to apex subequal 
in length but not in width, the whole flagellum tapering gradually from base to apex, the ultimate joint very slender and cone-shaped. Mesoscutum and scutellum as in the female.

The mesoscutum and scutellum in both sexes when viewed under high magnification in balsam appear finely and uniformly reticulated, the reticulations more or less longitudinally elongated.

Notes from the types in the United States National Museum.

\section{Family EULOPHIDAE}

\section{PLEUROTROPIS TARSALIS (Ashmead)}

Holcopelte tarsalis Ashmead, Trans. Amer. Ent. Soc., vol. 21, 1894, p. 341.

Asecodes albitarsis Ashmead, Can. Ent., vol. 20, 1888, p. 103.

Pleurotropis tarsalis (Ashmead) Crawford, Proc. U. S. Nat. Mus., vol. 43, 1912, p. 178.

Pleurotropis ashmeadi Crawford, Proc. U. S. Nat. Mus., vol. 43, 1912, p. 178.

Crawford stated that no satisfactory means for distinguishing the females of tarsalis and ashmeadi could be found but that the males could be separated by the fact that in tarsalis the funicle was apparently 4-jointed, while in ashmeadi it was apparently 3-jointed.

C. F. W. Muesebeck, of the gypsy moth laboratory at Melrose Highlands, Massachusetts, recently sent the writer a series of 13 males and 12 females of Pleurotropis, all reared from cocoons of Apanteles melanoscelus collected at Franklin, New Hampshire, and recorded under Gypsy Moth Laboratory No. 12599c. Among these males are specimens duplicating in antennal characters as well as in every other way the type males of both tarsalis and ashmeadi. In all of them the flagellum beyond the ring-joints is comprised of five joints, but in some specimens all five joints are distinctly separated and shortly pedunculate, while in others the ultimate joint is closely joined to the penultimate, the peduncle apparently entirely lacking. The first mentioned condition is exactly that found in the type of tarsalis, while the last mentioned is similar to that of the type of ashmeadi. The series of males exhibits a distinct gradation from the one form of antenna to the other. The type females, as indicated by Crawford, are inseparable and agree in every way with the females of the Muesebeck series. There seems no reason to suppose that the latter rearing represents more than a single species and the writer is therefore convinced that tarsalis Ashmead and ashmeadi Crawford are the same species.

\section{DASYSCAPUS, new genus (OMPHALINI) ${ }^{7}$}

It is not easy to decide the correct position of this genus in the Eulophidae. It runs best in Ashmead's classification to the tribe

7 The description of Goetheana Girault (Ins. Ins. Mens., vol. 8, 1920, p. 97) fits this insect almost exaetly, but inasmuch as the author of that genus places it in the family Mymaridae, a group with which the present form has no relationship, and since the description is insufficient for positive identification, one is compelled to assume the two are not the same. 
Omphalini and in the key to genera of that tribe runs out at Closterocerus, a genus with which it has much in common but from which it may be easily distinguished by the narrow and immaculate wings with their long marginal cilia, by the noncompressed antennae, by the swollen scape in the male, and by the differently shaped head. In the swollen scape of the male, as well as in the number of antennal joints and in other ways, it seems to agree very well with Ceranisus Walker (which genus is placed in the Tetrastichini) but differs from Walker's figure of C. pacuvius Walker by the narrow wings, poorly developed stigmal vein, 1-jointed funicle, 4-jointed club, and the more broadly concave occiput. For the present, at least, it seems best placed in the tribe Omphalini.

Female and male.-Head viewed from above strongly transverse, the occiput broadly concave and forming a sharp angle with the vertex and temples; ocelli in a very low triangle; frons broad; antennae inserted below the middle of head, about on a level with the ventral eye margins; antennae 8-jointed (scape, pedicel, one very minute ring-joint, one funicle joint and a 4-jointed club), the scape slender and subfusiform in the female, enormously swollen in the male; pedicel in both sexes large, distinctly longer than the funicle joint; funicle joint longer than broad; club fusiform, compact, but the sutures distinct; pronotum concealed from above; mesonotum short, much broader than long, with a very weak median groove, and the parapsidal grooves inconspicuous but apparently present; scutellum without dorsal grooves; postscutellum conspicuous; propodeum short without conspicuous folds or carinae, the spiracular grooves more or less impressed; forewings small and narrow with a long marginal fringe, the marginal vein long, much longer than the snbmarginal, the stigmal short and inconspicuous, postmarginal absent, venation attaining to the apical quarter of wing; hind wing very narrow with the marginal fringe three or four times the wing breadth; tarsi 4-jointed; abdomen ovate, about as long as the thorax, with a very short petiole, the ovipositor not at all exserted.

DASYSCAPUS PARVIPENNIS, new species

Plate 1, fig. 1.

Female.-Length $0.60 \mathrm{~mm}$. Head, thorax, and abdomen smooth and polished; antennal scape rather long, slightly thicker near base than at apex; pedicel equal in length to the ring joint and two following joints combined, distinctly thicker than the funicle; funicle joint a little longer than broad; club 4-jointed, approximately as long as the scape and as thick as the pedicel, the joints subequal in length, the apical joint somewhat the longest and terminating in a short spine; each of the flagellar joints set with several long bristles; marginal fringe of forewing fully twice as long as the width of wing. Head 
and thorax black, the face more or less brownish; antennae, legs including all coxae, and the abdomen pale yellowish, the abdomen with a small brownish or blackish spot on each side near apex; wings hyaline.

Male.-Length $0.55 \mathrm{~mm}$. Scape greatly swollen and dark brownish in color; apical one-third of abdomen black; otherwise exactly like the female.

The size is variable in both sexes, the length ranging from $0.55 \mathrm{~mm}$. to $0.65 \mathrm{~mm}$. in the females and from $0.45 \mathrm{~mm}$. to $0.60 \mathrm{~mm}$. in the males.

Type locality.-Buitenzorg, Java.

Cotypes.-Cat. No. 29450, U.S.N.M.

Described from 6 females and about 150 males mounted in balsam on 12 slides, and 1 female and 34 males mounted on card points. This material was all received by the Bureau of Entomology from W. C. Van Heurn, Buitenzorg, Java, with the information that it was reared from Thrips tabaci along with Thripoctenus brui Vuillet and was believed to be a secondary parasite.

Van Heurn published a figure and description of this insect together with some account of its habits ${ }^{8}$ but did not name it. It is at his suggestion transmitted through Dr. L. O. Howard that the writer has undertaken to name it here.

\section{ASTiCHUS PULChRILINEATUS, new species}

Plate 1, fig. 2

This species is extremely similar to the description and figure of A. longivittatus $\mathrm{Masi}^{9}$ and may possibly be the same, but the females apparently have the abdomen somewhat longer and more slender than indicated by Masi's figure, the ovipositor appears to be a little more prominent, the hyaline band at apex of forewing appears broader, and the head appears to be less narrowed behind the eyes. Both pulchrilineatus and longivittatus differ from typical Astichus as represented by $A$. arithmeticus Foerster (of which the National Collection possesses one specimen determined by Dr. Franz Ruschka and taken at Bleicherode, Saxony) as follows: The stigmal vein is much more oblique and distinctly longer than the postmarginal, the apical margins of first and second tergites are emarginate at the middle, the dorsum of thorax is very finely and opaquely sculptured, while the infuscation of the forewing is not nearly so dark and is much less broken by hyaline spots. In arithmeticus the stigmal vein is nearly perpendicular to the wing margin, the postmarginal is as long as stigmal, the abdominal tergites are not emarginate, the dorsum of thorax is weakly reticulated but shining, while the infusca- 
tion of the forewing is very dark and broken by numerous hyaline spots.

Female.-Length $1.35 \mathrm{~mm}$. Head viewed from in front subtriangular, a little broader than high, the antennal groove deep and extending to the front ocellus and only a little broader below than above; antennae inserted below the eyes; head, viewed from above, as broad as thorax, about twice as broad as long; occiput concave and immargined; vertex broad and flattened, nearly horizontal; frons vertical and forming nearly a right angle with the plane of vertex; ocelli in an obtuse triangle, the front ocellus at the anterior margin of plane formed by vertex, the posterior ocelli about as far in front of the occiput as distant from each other; head granularly punctate and opaque above, the cheeks and lower portion of temples finely reticulate and shining; antennae 10-jointed; scape subcylindrical; pedicel almost twice as long as broad, longer and narrower than the first funicle joint; one very small transverse ring joint; funicle 4-jointed, the joints subequal in length and subquadrate, all thicker than the pedicel, the dorsal margin of first slightly oblique; first and second joints very slightly thicker than the third and fourth; club ovate, a little longer than the two preceding funicle joints combined, distinctly thicker than the funicle, the sutures very indistinct; pronotum short; parapsidal grooves complete; mesoscutum and scutellum sculptured like the head, the scutellum longer than broad, moderately convex and without dorsal grooves; propodeum reticulatepunctate but more weakly sculptured and more shining than the scutellum, without distinct lateral folds but with a very delicate median carina; spiracles minute; mesepimeron mostly polished, remainder of pleura sculptured like the dorsum of thorax; forewings reaching to apex of abdomen; abdomen about twice as long as head and thorax, smooth and shining, the first and second tergites emarginate at the apical middle; ovipositor slightly exserted. Head dark metallic green or purplish beneath; frons purplish black with about four transverse spots or bands of metallic green on each side along the inner eye margins, the antennal groove metallic green; vertex purplish black with three longitudinal stripes of bright metallic green and an additional spot of the same color behind each eye; antennae aeneous black, a spot at extreme base of scape and the fourth funicle joint either entirely or for the most part white, its apex sometimes blackish; thorax purplish black with three longitudinal stripes of metallic green extending from the anterior margin of praescutum to the apex of scutellum and a shorter, less distinct, longitudinal stripe on each scapula and extending on to the axillae; propodeum and pleura violaceous; wings hyaline at base and apex with a small fuscous spot at apex of submarginal vein and a large fuscous cloud embracing the whole width of wing behind the marginal and stigmal 
veins and ending distally in a broad curve; all coxae and femora black tinged with purple; hind tibiae black; anterior and median tibiae black at base and apex with a yellowish band, more or less variable in extent, beyond the middle; abdomen black or brownish black, more or less strongly kinted with purple and green.

Male.-Length $0.80 \mathrm{~mm}$. Similar to the female except that the second and third funicle joints are distinctly pedunculated at apex, the fourth funicle joint is concolorous with the rest of antennae, the peduncles on the second and third funicle joints are pale, the metallic green lines on head and thorax are not quite so conspicuous, the infuscation of the wings is a little less strong and the abdomen is elliptical in outline.

Type locality.-Difficult Run, Virginia.

Type-Cat. No. 28769 , U.S.N.M.

The holotype female, three paratype females and six males, including the allotype reared by $\mathrm{E}$. A. Chapin from a sporophore of the fungus Fomes fomentarius in which Brachycis brevicollis Casey were present. This mass of fungi was taken at the mouth of Difficult Run, a small stream emptying into the Potomac a few miles west of Washington, D. C. Two paratype females were taken by H. S. Barber, October 29, 1922, from a sporophore of Poria inermis which was infested by Brachycis brevicollis. These adults as well as larvae and pupae of the parasite were found in the burrows of the beetles by Mr. Barber. A single female paratype was found by Mr. Barber in a sporophore of Polyporia gilvus infested by Brachycis and Ceracis received from a correspondent from New York City.

\section{EUPLECTRUS JUNCTUS, new species}

Differs from $E$. catocalae Howard and frontalis Howard by having the abdomen devoid of any black at apex. May be distinguished from platyhypenae Howard and marginatus Ashmead by the white marked face, and from comstocki Howard, leucotrophis Howard, semimarginatus Girault, and pachyscapha Girault by the more distinctly sculptured scutellum in which it resembles bicolor Walker but is readily distinguished from that species by the almost wholly testaceous abdomen.

Female.-Length $2 \mathrm{~mm}$. Antennal scape normal, pedicel about two-thirds the length of first funicle joint; funicle joints successively diminishing slightly in length, the first about twice as long as broad, the fourth very slightly longer than broad; club short, conic-ovate, about as long as first funicle joint; head mostly smooth, the frons above and the occiput very finely and obscurely reticulated, and a few weak setigerous punctures along the inner eye margins; anterior face of pronotum scaly-punctate, the posterior margin polished; mesoscutum finely rugulose, parapsidal grooves very distinct, the 
praescutum with a very fine but distinct median longitudinal carina; scutellum very finely but distinctly reticulate, subopaque except at apex which is polished; axillae less distinctly reticulate; propodeum polished, the median carina distinct; pleura and sternum mostly polished but with the prepectus and femoral depression faintly rugulose; wings normal; front femora considerably swollen, thicker than the hind femora; innner spur of hind tibia equal in length to to the first and second tarsal joints combined; outer spur more than half as long as the inner one; petiole of abdomen rugulose and about twice as broad as long; abdomen, exclusive of petiole, as broad as long and broadest near apex. Head, thorax, abdominal petiole and narrow lateral margins of first tergite black; antennal flagellum brownish, becoming darker toward apex; scape and pedicel reddish testaceous, the scape paler basally; face below antennae and exclusive of cheeks, legs including all coxae, and abdomen except petiole and narrow margins on first segment, reddish testaceous; wings hyaline, venation pale testaceous.

Type locality.-Waldo, Florida.

Type.-Cat. No. 29451, U.S.N.M.

Host.-Isoparce cupressi Boisduval.

Described from three female specimens received from D. Marston Bates, Gainesville, Florida, and said to have been parasitic upon larvae of the above-named sphingid moth, taken by T.H. Hubbell in a cypress swamp, October 13, 1924.

\section{Family MYMARIDAE}

\section{Genus ANAPHOIDEA Girault}

So far as known to the writer, the curious arrangement of the ovipositor in this group has never been brought out. This will be best understood from a study of the accompanying figure of the abdomen of $A$. calendrae, new species (fig. 2).

The ventral portion of the abdomen is projected forward underneath the thorax, often reaching to the front coxae or even beyond. The ovipositor (fig. $2 ; O$ ) has its origin from the invaginated eighth and ninth sternites (fig. $2 ; 8 S$ and $9 S$ ) which are situated near the middle of the abdomen. From its point of origin the ovipositor first runs forward within the membranous sack formed by the anteriorly produced sternites and then bends sharply back upon itself and extends to the apex of the abdomen. In dead specimens this sack is frequently ruptured and the ovipositor appears as a distinct loop beneath the thorax. The ovipositor sheaths do not extend beyond the apex of abdomen. The actual point of emergence of the ovipositor from the abdomen is almost beneath the point of attachment of abdomen and propodeum. From this point to the apex of abdomen the ovipositor, when at rest, lies concealed in a groove formed in part by a 
large pair of elongate plates (fig. $2 ; 8 T$ ) which are apparently ventrally produced lobes of the eighth tergite, and in part by another pair of plates (fig. $2 ; 9 T$ ) which are apparently formed from the ninth tergite. The ovipositor sheaths (fig. $2 ; S$ ) lie between these two lastmentioned plates and do not extend beyond the apex of abdomen. The sternites are apparently completely fused.

The length of the ovipositor and the degree to which it is projected forward under the thorax varies for the different species, this new species having a longer ovipositor than any of the others represented in the national collection.

In the genus Anaphes Haliday which is very closely related to Anaphoidea the venter of the abdomen is usually not projected underneath the thorax, although in the genotype species it is somewhat triangular at base. In Anaphes pallipes Ashmead, however, the ovipositor and the venter are exactly as in Anaphoidea despite the fact

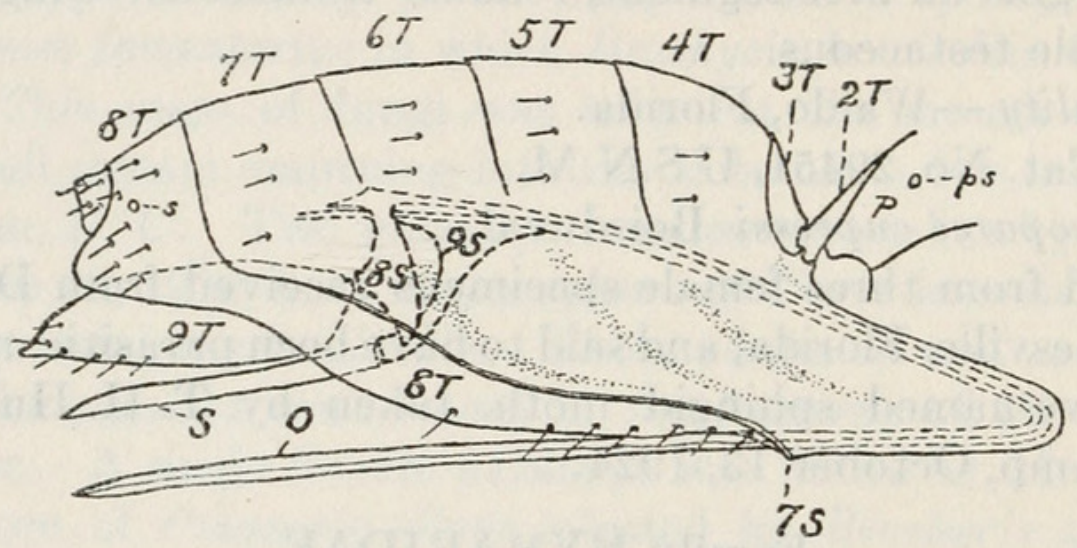

Fig. 2. Anaphoidea calendrae Gahan. Diagram of female abdomen. P, Propodeum; $p$, pro; PODEAL SPIRACLE; $2 T$, SECOND TERGITE; $3 T$, THIRD TERGITE; $4 T$, FOURTH TERGITE; $5 T$, FIFTH TERGITE$6 T$, SIXTH TERGITE; $7 T$, SEVENTH TERGITE; $8 T$, EIGHTH TERGITE; $9 T$, NINTH TERGITE; 0 , OVIPOSITOR; 2 , SPIRACLE; $S$, OVIPOSITOR SHEATH; $7 S$, SEVENTH STERNITE; $8 S$, EIGHTH STERNITE; $9 S$, NINTH STERNITE

that the antennae are 9-jointed, the club not divided. Males of Anaphes and Anaphoidea are apparently indistinguishable and it is not improbable that the two genera will eventually have to be merged in one.

Idiocentrus, the new genus described herewith, resembles Anaphoidea in having the ovipositor and the venter of abdomen greatly produced anteriorly, but is quite different in antennal and thoracic characters and the abdomen is quite differently shaped, with the ovipositor sheaths distinctly exserted.

\section{ANAPHOIDEA CALENDRAE, new species}

Very similar to pullicrura Girault, but may be distinguished from that species as well as from other closely related species by the fact that the basal joint of each tarsus is distinctly longer than the second joint. The abdomen of the female is also somewhat longer and more acute at apex, the ovipositor longer and projected further for- 
ward under the thorax, and wings narrower than in most of the other species.

Female.-Length of holotype $0.60 \mathrm{~mm}$.; of paratypes varying from $0.40 \mathrm{~mm}$. to $0.90 \mathrm{~mm}$. Antennae 10 -jointed, inserted at the middle of front of head, about as long as the insect; scape reaching to the vertex, a little more than three times as long as broad, broadest at the middle, the dorsal margin nearly straight, ventral margin slightly convex; pedicel cone-shaped, very nearly half as long as scape, and half as wide at apex as long; first funicle joint small, approximately half as long as pedicel; second funicle joint about three times as long as the first, and four to six times as long as thick; third joint equal to the second; joints 4 to 6 each slightly shorter than the third and gradually increasing in thickness; club not quite twice as long as the sixth funicle, but distinctly thicker, elongate-ovate, 2 -jointed, the joints subequal, the suture slightly oblique and not easily seen except in balsam-mounted specimens. Head about as broad as high without distinct sculpture, shining. Thorax mostly smooth and shining, with some very faint traces of reticulation on the mesoscutum and scutellum; parapsidal grooves complete but delicate; propodeum polished. Forewings narrow, about four-fifths as broad at the apex of venation as at the broadest part of blade, the posterior margin slightly concave; longest marginal cilia slightly longer than greatest width of wing; base of wing bare except for a single bristle behind the submarginal opposite the apex of submarginal; the area behind the marginal and stigmal veins with one oblique and slightly curved row of cilia extending from near the base of marginal to the posterior margin; from apex of venation to middle of wing mostly bare but with an irregular longitudinal row of cilia near the posterior margin and another median one dividing this region into an anterior and a posterior bare area; the apical half of wing uniformly ciliated; hind wing as long as forewing, narrow, with a row of discal cilia around the margin and in the apex of wing a median row usually consisting of about 4 cilia. Basal joint of all tarsi very distinctly longer than the second joint. Abdomen conic-ovate, dorsally about as long as head and thorax, the venter projected anteriorly beneath the thorax to form a membranous sack which reaches to the head and within which the looped ovipositor is plainly visible; ovipositor unusually long, extending anteriorly within the membranous pouch formed by the venter to reach the head and then curving back to the apex of abdomen but not exserted at apex. Head, thorax, abdomen and coxae polished black; femora usually dark brown, tibiae and tarsi reddish testaceous; antennae dark brown or black, the scape and pedicel brownish testaceous; wings faintly fuscous. 
Male.-Length $0.50 \mathrm{~mm}$. Agrees with the female except that the antennae are 12-jointed, twice as long as the insect, the pedicel about one and one-half times as long as thick, the funicle joints subequal in length, the first about four times as long as thick at apex; abdomen shorter than the thorax, its venter not produced anteriorly.

Type locality.-Kirkwood, Missouri.

Cotypes.-Cat. No. 29454, U.S.N.M.

Deseribed from one hundred and twenty-three specimens comprising several series and representing several generations reared through different hosts, received from A. F. Satterthwaite, of the United States Bureau of Entomology, field laboratory located at Webster Groves, Missouri. This material is as follows: Five females reared from eggs of Calendra? minima collected in the field at Kirkwood, Missouri, July 3, 1924, and recorderd under Webster Groves No. 24.106; four females and one male (progeny of those under No. 24106) reared from eggs of $C$. destructor in laboratory under Webster Groves No. 24117; seven females (progeny of those under No. 24117) reared in laboratory from eggs of $C$. callosa under Webster Groves No. 24153; nine females and one male (likewise progeny of No. 24117) reared from eggs of $C$. costipennis in laboratory under Webster Groves No. 24168. A second series consists of five females reared from the egg of $C$. parvula collected in the field on timothy at Kirkwood, Missouri (Webster Groves No. 24086) ; seven specimens, progeny of the foregoing, produced through eggs of $C$. parvula in the laboratory (Webster Groves No. 24110) ; and five specimens, progeny of No. 24110, produced through eggs of $C$. pertinax (Webster Groves No. 24134). The species was also successfully bred through eggs of $C$. maidis, seven specimens being obtained (Webster Groves No. 24157). The remaining 72 specimens of the type series were obtained in the same manner as those already listed and involve the same host species, but some were obtained from different localities. In order that these localities may be recorded and this type material identified it may be listed as follows: Webster Groves No. 22135a, Grenada, Mississippi; No. 22125n, Greenville, Mississippi; No. 22150p, Boschertown, Missouri; No. $22174 b$ and 22174c, Webster Groves, Missouri; No. 24109, No. 24118, No. 24135, No. 24138, No. 24156, No. 24169, No. 24159, No. 24130, and No. 24125, Kirkwood, Missouri.

One hundred and eleven specimens of the type series, including the holotype and allotype, are mounted in balsam on 41 slides; 12 paratypes are mounted on card points.

There is a wide variation in size of individuals in this series, the length of females ranging from $0.40 \mathrm{~mm}$. to $0.90 \mathrm{~mm}$. with a corresponding variation in other dimensions. The size of individuals is directly correlated with the size of the host egg and the number of individual parasites harbored by it. The largest individuals were 
those obtained from the relatively large egg of $C$. maidis and the smallest were bred from eggs of $C$. minima. Aside from this variation in size, however, the series presents a surprisingly small amount of deviation from type. There is some variation in the relative lengths of the funicle joints and to a very slight extent in the proportions of the wings; the median row of discal cilia in the apex of hind wing may contain as many as six cilia or may be entirely absent; the femora in some individuals lack almost entirely the dark brownish infuscation; in other respects the series seems to be uniform.

Seldom is a taxonomist privileged to study a series of specimens such as this, and my thanks are due to Mr. Satterthwaite for the opportunity.

\section{IDIOCENTRUS, new genus}

Probably most nearly related to Polynemoidea Girault and Stethynium Enoch but differing from both in the extraordinary forward extension of the venter of the abdomen beneath the thorax. The nearest approach to this character known to the writer is found in the genus Anaphoidea Girault in which the venter at base is somewhat prolonged downward and forward but to a much less extent than in the present genus. Anaphoidea may be readily separated from Idiocentrus by the fact that the antennal club is 2-jointed instead of 3-jointed, the antenna 10-jointed instead of 11-jointed, the abdomen much shorter and the ovipositor scarcely exserted beyond the tip of abdomen.

Female.-Long and slender. Abdomen much longer than the head and thorax, completely sessile, with the ventral segments modified to form a membranous pouch or sheath which extends forward beneath the thorax and between the legs to reach the head, the ovipositor extending forward within this pouch to its anterior extremity and then folding back and running posteriorly to the apex of abdomen where it emerges, its sheath exserted about one-fifth the length of abdomen. Antennae 11-jointed, the club indistinctly 3-jointed; funicle joints all rather long; thorax slender and distinctly longer than broad; pronotum rather large and conical anteriorly; parapsidal grooves present and the mesoscutum with a fine median longitudinal groove; scutellum somewhat longer than broad; axillae small and broadly separated; metanotum short and transverse; propodeum about as long as the scutellum and metanotum together, broad; legs long and slender; front femora somewhat longer than either of the other pairs; hind trochanters nearly as long as their coxae; front tibial spur distinctly forked at apex; tarsi 4 -jointed; forewings broad, marginal vein about twice as long as stigmal, submarginal vein at the margin of wing, no costal cell present; hind wings narrow.

Type of the genus.-Idiocentrus mirus, new species. 


\section{IDIOCENTRUS MIRUS, new species}

Female.-Length $1.5 \mathrm{~mm}$. Antennae about half as long as the body; scape approximately three times as long as broad; pedicel ovate, about one and one-half times as long as broad, much thicker than the funicle; funicle 6-jointed, the joints cylindrical; first funicle about as long as pedicel and approximately two-thirds as long as thick; third to sixth successively decreasing very slightly in length, the sixth fully two-thirds as long as the second; club a little longer than the two preceding joints combined, distinctly thicker than the last funicle joint, with three subequal joints, the sutures not very dis-

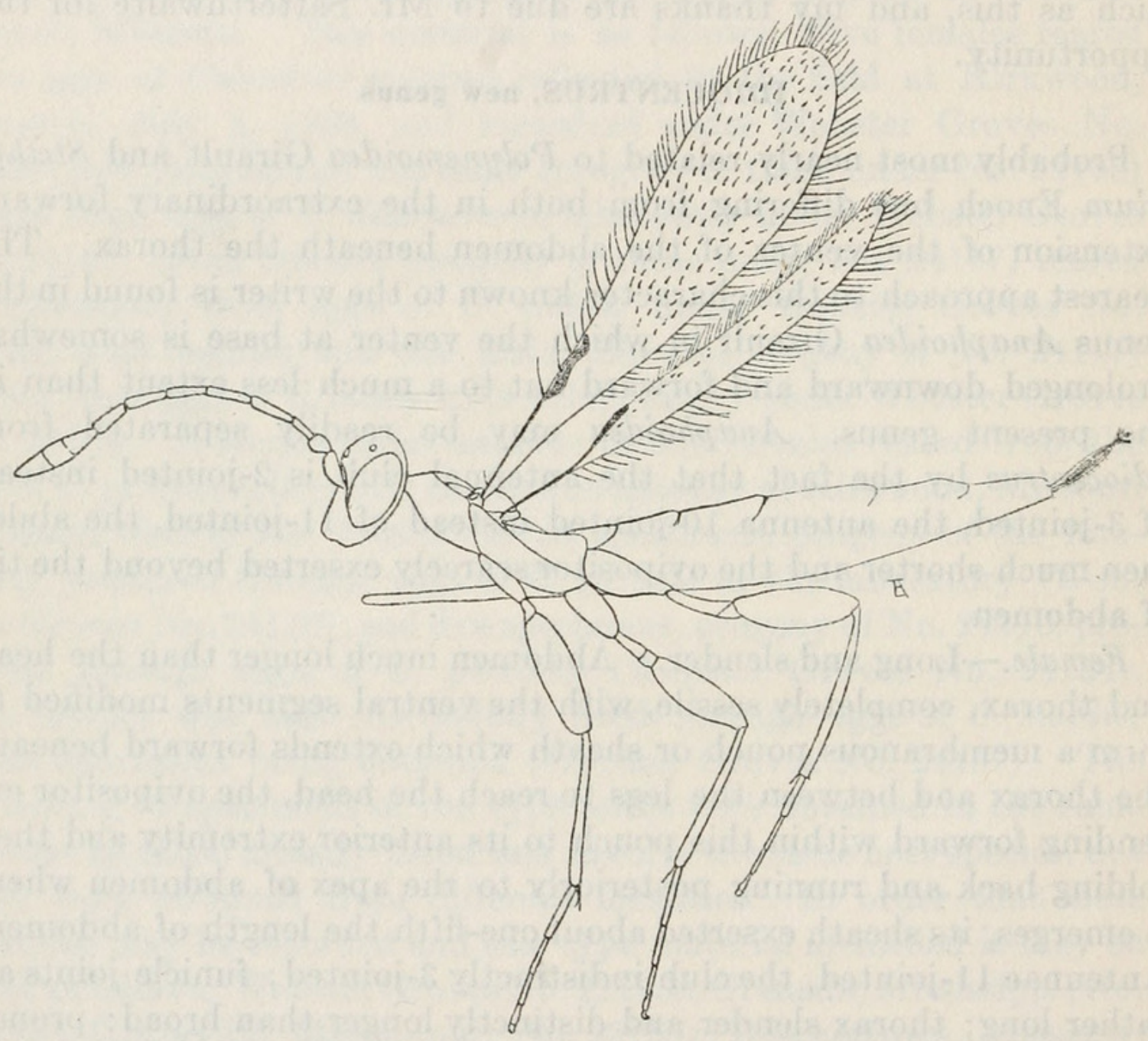

Fig. 3.-IDiocentrus Mirus Gahan, ADUlt FEMale

tinct. Head collapsed so that it is impossible to make out the characters. Pronotum and mesoscutum faintly sculptured; scutellum smooth; propodeum broad with distinct lateral folds but without a median carina, and very faintly if at all sculptured; abdomen broadly sessile, fully twice as long as thorax, compressed from the sides and acute at apex; ovipositor sheaths about one-fifth as long as abdomen; forewings bare at base, the bare area extending nearly to middle of wing on the anterior margin and very slightly beyond apex of venation on the posterior margin; apical half of wing with moderately dense discal cilia; longest marginal cilia equal to a little less than 
half the wing width; venation extending one-third the length of wing, the submarginal vein very slender and placed on the margin of wing (no costal cell present); marginal and stigmal much thicker, the marginal equal to about one-third the length of submarginal, the stigmal equal to one-half the marginal; hind wing petiolate at base, the blade parallel-sided except at apex which is subacute; discal ciliation on basal half of blade consisting of a single row of cilia, on the apical half composed of several irregular rows; the marginal cilia on hind margin of blade distinctly longer than width of blade, those on front margin shorter; all tibiae much longer than their femora, the posterior pair nearly twice as long; tarsi slender, the fore and median pairs equal in length to their tibiae, the posterior pair about twothirds as long as their tibiae. General color brownish-black, the head above yellowish; antennae dark brown or blackish, the scape and pedicel somewhat paler; scutellum brownish testaceous, the mesoscutum also more or less brownish; all coxae and femora brownish, the tibiae and tarsi testaceous; wings hyaline with a slight infuscation behind the marginal and stigmal veins. Male unknown.

Type-locality.-York Bay, New Zealand.

Type-Cat. No. 29452, U.S.N.M.

Described from two females received from J. G. Myers and said to have been reared from the eggs of the cicada, Melampsalta muta Fabricius.

The specimens from which this species is described are not in perfect condition, the head being badly collapsed and the thorax and abdomen more or less shriveled. Consequently it is impossible to describe the species more fully. Likewise the figure, while it gives a good idea of the general appearance of the insect, may not be entirely accurate as to shape of head, position of ocelli, and size and shape of the sclerites of the thorax and abdomen, since it was impossible to make sure of these details.

\section{Superfamily SERPHOIDEA}

\section{Family SCELIONIDAE}

HADRONOTUS ATRISCAPUS, new species

Differs from $H$. robustus Brues by having the second tergite about twice as broad as long and without indication of longitudinal rugae except at extreme base, the third tergite much less than half as long as the second. May be distinguished from ajax Girault, carinatifrons Ashmead, anasae Ashmead, floridanus Ashmead, rugosus Howard, and rugiceps Ashmead by the dark scape and legs, and from the remaining North American species except rugosithorax Ashmead by the larger size and coarser sculpture of thorax. Agrees with the 
description of rugosithorax Ashmead in color but differs desidedly in the proportions of the abdominal tergites.

Female.-Length, $1.6 \mathrm{~mm}$. Moderately robust; head broader than thorax; occiput above with about four irregular rugae extending from eye to eye; vertex finely punctate, opaque; frons and face laterad of antennal depression coarsely punctato-rugulose; antennal depression distinctly margined above and transversely striated, the striae a little more distinct below than above; cheeks more finely punctate than the face; ocelli in an obtuse triangle; first funicle joint as long as pedicel, second a little longer than broad; third about as long as broad; fourth and fifth broader than long; club moderately thick, all joints, except the last, slightly broader than long, the ultimate joint conical; mesoscutum strongly convex and rugose, the rugae irregular but distinctly longitudinally directed on the posterior portion of this sclerite; scutellum rugose, margined apically and latterally, the rugae not longitudinal; propodeum rugoso-punctate; mesopleura irregularly longitudinally rugose; metapleura rugose but not longitudinally so; marginal vein two-thirds as long as stigmal; the postmarginal more than twice as long as stigmal; abdomen a little broader than the thorax, a little broader than long; first tergite longitudinally striated, the striae well separated with the intervening areas nearly smooth; second tergite about twice as broad as long, more than twice as long as the first, evenly rugulose-punctate without longitudinal rugae except at extreme base; third not over onefourth as long as second and similarly but a little more finely sculptured; following tergites very short; venter closely punctate. Black; extreme base of scape, trochanters, all tibiae and all tarsi rufo-piceus to rufo-testaceous; antennae, except base of scape, black, and all coxae and femora black; wings hyaline.

Male.-Similar to the female except that the antennae are not clubbed, the first flagellar joint is longer than the pedicel, the following joints to penultimate are subequal and subquadrate, and the femora are rufo-piceus.

Type locality.-Uvalde, Texas.

Type-Cat. No. 29453, U.S.N.M.

Type and three paratype females reared from eggs of Narnia pallidicornis Stal, by A. P. Dodd at Uvalde, Texas, in August, 1924. Two males, including the allotype, and fifteen female paratypes reared from eggs of the same host insect at Uvalde, Texas, in August, 1923, by J. C. Hamlin; and three females and one male from eggs of Narnia femorata Stal, Brownsville Texas, August, 1922, by T. C. Barber. 


\section{Family PLATYGASTERIDAE}

AMITUS ALEURODINIS Haldeman

Amitus aleurodinis Haldeman, Amer. Jour. Sci. and Arts, ser. 2, vol. 9, 1850, p. 110.

Elaptus aleurodis Forbes, 14th Rept. Ent. Ill., 1884, p. 110, pl. 11, fig. 6.

Alaptus aleurodis Cresson, Syn. Hym. North Amer., 1887, p. 250.

Amitus aleurodinis Cresson, Syn. Hym. North Amer., 1887, p. 250.

Anaphes mellicornis Ashmead, Can. Ent., vol. 19, 1887, p. 194.

Amitus aleurodinis Asrmead, Bull. 45, U. S. Nat. Mus., 1893, p. 293.

Anaphes mellicornis Girault, Trans. Amer. Ent. Soc., vol. 37, 1911, p. 279.

Amitus aleurodinis Fouts, Proc. U. S. Nat. Mus., val. 63, 1924, p. 9.

Girault has pointed out that Anaphes mellicornis Ashmead is not a Mymarid but a Serphoid, without, however, attempting to determine its real relationship. The type in the National Museum has been examined and is in my opinion identical with Amitus aleurodinis Haldeman.

The species is apparently widely distributed, the following distribution being shown by the material in the national collection: Amherst, Massachusetts, parasitic on Aleurodes fernaldi, A. W. Morrill, collector, September, 1906; Whitesbog, Pemberton, New Jersey, parasite of Aleuroplatus plumosa on cranberry, H. B. Scammell, collector, March 5, 1915; Haddam, Connecticut, parasitic on the same host, W. E. Britton, collector, June 27, 1920; southern California, bred from Aleurodes, species, on Rhus, May, 1908, collector not given; Jacksonville, Florida, W. H. Ashmead, collector; Guanajuato, Mexico, A. Dugio, collector, June, 1903; four specimans, without locality, reared from "maple leaf Aleurodes February 20, 1874." The types, which are in the Academy of Sciences of Philadelphia, were reared from an Aleurodid on Cornus in Pennsylvania. The types of the Forbes description were from (Aleurodes) Aleurochiton forbesii (Ashmead) in Illinois. Ashmead records the species from the vicinity of Washington, but I have been unable to locate his specimens.

\section{EXPLANATION OF PLATE}

Fig. 1. Dasyscapus parvipennis Gahan, adult male; 1a, antenna of female.

2. Astichus pulchrilineatus Gahan, adult female; $2 a$, antenna of male; $2 b$, antenna of female.

3. Anastatoidea brachartonae Gahan, adult female. 


\section{$2 \mathrm{BHL}$ Biodiversity Heritage Library}

Gahan, A. B. 1927. "Miscellaneous descriptions of new parasitic Hymenoptera with some synonymical notes." Proceedings of the United States National Museum 71(2676), 1-39. https://doi.org/10.5479/si.00963801.71-2676.1.

View This Item Online: https://www.biodiversitylibrary.org/item/32439

DOI: https://doi.org/10.5479/si.00963801.71-2676.1

Permalink: https://www.biodiversitylibrary.org/partpdf/32794

\section{Holding Institution}

Smithsonian Libraries

\section{Sponsored by}

Smithsonian

\section{Copyright \& Reuse}

Copyright Status: NOT_IN_COPYRIGHT

Rights: https://www.biodiversitylibrary.org/permissions/

This document was created from content at the Biodiversity Heritage Library, the world's largest open access digital library for biodiversity literature and archives. Visit BHL at https://www.biodiversitylibrary.org. 